\title{
Türkiye'de Finansal Krizlerin Öncü Göstergelerle Tahmini
}

\author{
Predicting Financial Crises in Turkey by Leading Indicators
}

\author{
Dr. Öğr. Üyesi Dilara AYLA $\left(D^{1}\right.$
}

$\ddot{\mathbf{O z}}$

Bu çalışma, Türkiye'de 1994:01-2018:11 döneminde gerçekleşen finansal krizlerin ekonomi literatüründe belirtilen finansal kriz göstergeleriyle olan ilişkilerini irdelemek amacını taşımaktadır. Çalışmada kullanılan göstergeler; bütçe açı̆̆ının GSYİH'ya oranı, cari açı̆̆ın GSYİH'ya oranı, enflasyon oranı, faiz oranı, kapasite kullanım oranı, TCMB döviz varlıkları, döviz kuru, ithalat, para arzı ve sanayi üretim endeksini içermektedir. Bu kapsamda teorik altyapıya uygun olarak belirlenen kriz dönemleri ve göstergeler arasındaki ilişkilerin ortaya konulabilmesi amacıyla Probit analizinden yararlanılmıştır. Yapılan analizde kriz göstergelerinin finansal kriz olma olasılığı üzerindeki etkileri yön bakımından tespit edildiği gibi söz konusu göstergelerin marjinal etkilerinin hesaplanması ile birlikte bu değişkenlerin finansal krizlerin olma olasılığı üzerindeki etki katsayıları da belirlenmiştir. Analiz sonucunda enflasyon oranı, faiz oranı ve para arzı değişkenlerinin finansal kriz olma olasılığı üzerinde pozitif; diğer değişkenlerin ise negatif yönde etkide bulunduğu tespit edilmiştir. Marjinal etki hesaplamaları ile ulaşılan sonuçlara göre enflasyon oranı değişkeninin kriz olasılığı üzerindeki etkisinin oldukça yüksek olduğu tespit edilmiştir. Bu çerçevede yıllardır enflasyonla mücadele eden Türkiye ekonomisinin sürdürülebilir bir enflasyon oranının temini için yeni politikalar üretmesi gerektiği yorumu yapılabilecektir. Bu sebeple öncü kriz göstergelerinin dikkate alındığı ekonomi politikalarının daha hassas bir şekilde uygulanması ve yapısal düzenlemelere ilişkin planlara ağırlık verilmesi önerilmektedir

Anahtar Kelimeler: Finansal kriz göstergeleri, probit, marjinal etki

Makale Türü: Araştırma

\begin{abstract}
In this study, it is intended to analyze relations between financial crisis in Turkey in the period of 1994: 01-2018:11and financial crisis indicators specified in financial literature of economies. The indicators used in the study include the ratio of the budget deficit to the GDP, the current account deficit to GDP ratio, inflation rate, interest rate, capacity utilization rate, CBRT foreign exchange assets, exchange rate, import, money supply and industrial production index. In this context, Probit analysis was used to determine the relationship between the crisis periods and indicators determined in accordance with the theoretical infrastructure. In the analysis, the effects of the crisis indicators on the probability of financial crisis were determined in terms of direction as well as the calculation of the marginal effects of these indicators and the effect coefficients of these variables on the probability of financial crises. As a result of the analysis, the inflation rate, interest rate and money supply variables were positive on the probability of financial crisis, other variables were found to have a negative effect. According to the results obtained with the marginal effect calculations, the effect of the inflation rate on the probability of the crisis was found to be quite high. In this context, Turkey's economy for many years struggling with inflation, new policies for the provision of a sustainable inflation rate in Turkey's economy must generate. For this reason, economic policies should be applied more precisely and the plans for structural regulations should be taken into consideration. Therefore, the economic policies in which the leading crisis indicators are taken into account should be implemented more precisely and the plans for structural arrangements should be given more weight.
\end{abstract}

Keywords: Financial crisis indicators, probit, marginal effect

\footnotetext{
${ }^{1}$ Recep Tayyip Erdoğan Üniversitesi, Fındıkı Uygulamalı Bilimler Yüksekokulu, dilara.ayla@erdogan.edu.tr.
} 
Paper Type: Research

Giriş

Finansal krizler ve bu krizlerin yarattığı etkilerin sadece krizin çıktığı ülkede değil diğer ülkelerde de kendini göstermesi, finansal krizleri dünya çapında tartışılan bir olgu haline getirmiştir. Finansal serbestleşme süreciyle birlikte hız kazanarak sıklıkla görülmeye başlayan bu krizler ekonomi dizininde pek çok araştırmaya konu olmuştur. Genel olarak değerlendirildiğinde söz konusu krizlerin gelişmekte olan ülkeler üzerindeki maliyetinin gelişmiş ülkelere göre daha fazla olduğu söylenebilecektir. Bu nedenle finansal kriz olgusu, tarihi gelişimi ve özellikle krizler açısından gösterge niteliği taşıyan kavramların gelişmiş ve gelişmekte olan ülkelerdeki seyri üzerinde odaklanılması önem arz etmektedir.

Dünya ekonomisinde yaşanan krizler ele alındığında ilk finansal krizler 1825 ve 1827'de İngiltere'de gerçekleşmiştir. 1857-1933 döneminde gerçekleşen finansal krizlerin ise $\mathrm{ABD}$ ve İngiltere'de yaygın olduğu ifade edilebilir. Bu kapsamda ilgili kriz yılları ve etki alanları sırasıyla; 1857-İngiltere/Almanya, 1864-Fransa/İngiltere, 1866-Fransa/İngiltere, 1873ABD/Almanya/Avusturya, 1882-Fransa, 1889-Fransa, 1890-İngiltere, 1893-ABD, 1907-Fransa/ İtalya/ ABD, 1929-ABD, 1932 ve 1933-Dünya'dır. Bu dönemdeki en büyük finansal krizin 1929 yılında ABD'de yaşanan borsa çöküşünün ardından ortaya çıkan ve 1930'lu yıllar boyunca etkisini sürdüren Büyük Buhran'dır. Büyük buhran döneminde bankaların çoğu iflas etmiş, ayakta kalanlar ise önemli kayıplar yaşamıştır. Bu kriz ABD'de sadece bankacılık sektörünü olumsuz etkilemekle kalmamış, ABD GSMH'sı dört yılda yaklaşık \%30 azalmıştır (Stanford, 1998: 116). Krizin merkezi Kuzey Amerika ve Avrupa olmasına rağmen yaşanan olumsuzlar sanayileşmiş ülkeler başta olmak üzere dünyanın geri kalanını da etkilemiş, büyük boyutlarda işsizliğe ve ekonomik daralmaya neden olmuştur (Turan, 2011: 58).

1929 yılında yaşanan Büyük Buhran'dan 1960'lı yılların sonuna kadar Dünya ekonomisini etkileyen ciddi bir finansal kriz yaşanmamıştır. 1970 sonrası dönemde ise Brettoon Woods sisteminin çökmesi ve ciddi boyuttaki iki petrol krizinin etkisiyle Dünya ekonomisinde tekrar önemli finansal krizler gerçekleşmiştir. 1980'li yılların başında özellikle geri kalmış olan ülkelerin içine girdiği borç krizinin olumsuz etkileri uzun süre etkisini sürdürmüş ve küresel ekonomide önemli ölçüde daralmalara neden olmuştur (Delice, 2003: 66).

1990'l1 y1llarda başlayan ve halen devam eden finansal bütünleşme (entegrasyon) süreci ise ülke ekonomilerini birbirinden daha fazla etkilenir bir hale getirmiştir. Bu sürecin bir sonucu olarak bir ülkenin ekonomisinde yaşanan makroekonomik koşullardaki beklenmeyen veya öngörülemeyen olumsuz değişmeler söz konusu ekonominin finansal piyasasındaki istikrarsızlığın yanında uluslararası düzeyde finansal ve reel krizlere de yol açabilmiştir (Korkmaz ve Yamak, 2015: 51). Bu dönemde yaşanan finansal krizlerin en önemlileri 1992-93 Avrupa Döviz Kuru Mekanizması krizi, 1994-95 Tekila Krizi, 1994-95'de Türkiye para ve bankacılık krizleri, 1997-98 Asya Krizi, 1998 Rusya ve Brezilya krizleri, Kasım 2000 ve Şubat 2001 Türkiye krizleri ile 2001 Arjantin krizi olarak siralanabilir.

Avrupa Para krizi hariç yaşanan krizlerin her birinde sabit döviz kuru sistemleri, sermaye giriş ve çıkışları ile makroekonomik göstergelerde yaşanan bozuklukluların etkili olduğu görülmektedir. Ayrıca kamu otoritelerince hazine kaynaklarının aşırı kullanılması, vergi tabanındaki aşınmaların bir sonucu olarak kamu kesimi bütçe açıklarında yaşanan artış ve bu açıkların para basmak veya yurtiçi bankalardan borç almak suretiyle finanse edilmeye çalışılması bu krizlerin ortaya çıkmasında önemli rol oynamıştır. Bu noktada yüksek enflasyon yaşayan ekonomilerin, finansal istikrarın teminine yönelik rejimlere geçiş dönemlerinde de bu krizlere maruz kaldığını söylemek mümkündür (Delice, 2003: 66-67).

2008 yılına gelindiğinde ABD'deki Mortgage krizinin ortaya çıkmasında düşük gelirli ve kredi geçmişi zayıf olan hane halklarına yüksek faizle "sub-prime" konut kredileri verilmesi etkili olmuştur. $\mathrm{Bu}$ krizin ortaya çıkmasında rol oynayan etkenlerden bir diğeri de ABD 
ekonomisinin verdiği yüksek düzeyde cari açık olmuştur. Cari açı̆̆ın oluşmasının ve büyümesinin nedeni ise artan yatırım talebinin iç tasarruflarla karşılanamaması ve artan taleple birlikte ithalatın da artmasıdır. Bu kriz bir süre sonra ABD ile yakın finansal ilişkileri bulunan $\mathrm{AB}$ üyesi ülkelere sıçramıştır. 2011 yılı Avrupa borç krizini tetikleyen faktörler yüksek kamu borcu, bütçe açıkları ve cari açık ile ortak para birimine geçiş ve sonrasında yaşanan aksaklılardır. 2011 sonrası dönemde yayılma etkisi göstererek derin bir kriz yaşanmamakla birlikte literatürde sözü geçen kriz göstergelerinin ülkeler bazında kriz sinyalleri verdiğini söylemek mümkündür.

Bu çerçevede çalışmada, Türkiye ekonomisinin 1994:01-2018:11 dönemine ait aylık verilerinden yararlanılarak yaşanan finansal kriz dönemlerinde belirleyici olabilecek finansal kriz göstergelerinin kriz olma olasılı̆̆ üzerindeki etkilerinin tespit edilmesi amaçlanmaktadır. Bu kapsamda çalışmanın ilk ve ikinci bölümünde finansal kriz modelleriyle ilgili literatürden, üçüncü ve son bölümde ise araştırmanın yöntemi ve yapılan çözümleme sonucunda elde edilen tespit ve değerlemelere yer verilmiştir.

\section{Finansal Kriz Modelleri ve Öncü Göstergeleri}

İktisat yazını genel olarak değerlendirildiğinde finansal krizlerin nedenlerini ve boyutlarını ele elan üç farklı kriz modeli bulunmaktadır. Bunlar; birinci, ikinci ve üçüncü nesil kriz modelleri olarak adlandırılmaktadır.

Birinci nesil kriz modeli ilk olarak Krugman (1979) tarafından ortaya atılmış ve daha sonra Flood ve Garber (1984) tarafından geliştirilmiştir. Söz konusu klasik modeller tüketici optimizasyonu ve zamanlar arası bütçe kısıtlaması dâhil edilerek Obstfeld (1986), Calvo (1987), Drazen ve Helpman (1987) ve Van Wijnbergen (1991) tarafından da geliştirilmiştir (Ascarya, 2017: 502). Birinci nesil kriz modelleri, sabit döviz kuru rejiminin uygulanmasından kaynaklanan döviz krizlerinin ortaya çıkışını dövizdeki istikrarsızlık ve makroekonomik politikaların uygulanmasındaki tutarsızlıkla ilişkilendirmiştir (Doğan, 2009: 503). Krugman (1979), finansal krizlerin temel nedeninin sabit döviz kuru sistemi altında bütçe açıklarının kapatılması amacıyla genişletici para ve maliye politikalarının uygulanması olduğunu ileri sürmektedir. Hükümetin sabit döviz kuru rejimini sürdürmeye çalışırken, devamlılık gösteren kamu bütçe açıklarını para basmak suretiyle karşılamak zorunda kalması, sürekli bir şekilde rezerv kaybetmesine neden olmaktadır. Birbiriyle tutarlı olmayan bu iki özellik spekülatörlerin merkez bankası kaynaklarına yönelik olası saldırılarına neden olacak ve böylece sabit döviz kuru sistemi sürdürülemez hale gelecektir. Birinci nesil kriz modellerine göre devlet bütçesinin açık vermesi ve merkez bankasının sahip olduğu döviz rezervlerin azlığı döviz krizlerine neden olmaktadır. Dolayısıyla bütçe açıklarının sürekli bir şekilde para basılarak giderilmeye çalışılması az olan rezervleri de eritmektedir. Bu noktada devalüasyon olacağ $\breve{g}_{\text {korkusuna }}$ kapılan spekülatörler ellerindeki ulusal paraları dövizle değiştirmek için harekete geçecektirler. $\mathrm{Bu}$ süreçte Merkez bankalarının döviz rezervlerinin azalması ise, ulusal paraya yönelik spekülatif saldırıları daha da hızlandıracaktır. Bu durumda ise bir devalüasyon yaşanacak ve yaşanan devalüasyon finansal krizin başlamasına aracılık edecektir (Yılmaz vd., 2005: 89-90). Birinci nesil kriz modellerinin öncü göstergeleri arasında; bütçe açıkları, parasal genişleme, kamu harcamaları ve yurtiçi kredi hacmindeki genişleme, dış ticaret ve cari işlemler dengesindeki bozulma, reel döviz kurundaki değerlenme, iç borçlanmadaki artış, döviz kurunun yükselmesi, uluslararası döviz rezervlerindeki azalma, faiz oranlarındaki artış ve enflasyon oranındaki yükselme sayılabilir (Kaminsky, 2003: 21; Avcı ve Altay, 2013: 49; Akçalı, 2014: $35)$.

1992-1993 Avrupa Para krizinin ardından, birinci nesil kriz modellerinin sürmekte olan krizi açıklamakta artık yetersiz olduğu görülmüştür. Avrupa'da bu süreçte yaşanan gelişmeler, hükümetleri aktif olarak ekonomiyi canlandırma ve döviz kuru rejimini sürdürmek arasında karar vermek zorunda bırakmıştır. Bu durumda da sabit döviz kuru rejimine dayanan birinci nesil kriz modelleri yerine hükümetin politika tercihlerinin içselleştirildiği bir modele ihtiyaç 
duyulmuştur. Böylece Obstfeld (1994, 1996)'nın öncülüğünde ikinci nesil modeller ortaya çıkmıştır (Goldstein ve Razin, 2015: 159). Obstfeld (1996) Avrupa'da kriz esnasında sabit döviz kuru rejiminin uygulandığını ve güçlü finansal yapıya sahip olan Avrupa ülkelerinde tek başına spekülatif saldırıların krizi açıklamada yeterli olmayacağını belirtmiştir. Avrupa'da meydana gelen krizin ana sebebi uluslararası bir likidite sorunu olup uygulanan makroekonomik politikaların piyasa beklentileriyle uyuşmaması kaçınılmaz olarak döviz spekülasyonu ve döviz krizini gündeme getirmiştir. İkinci nesil kriz modellerinde hükümetler döviz kuru rejiminin sürdürülmesi veya terk edilmesi noktasında aktif bir rol oynamaktadırlar. Bu kriz modellerinde üç temel durum söz konusudur; birinci ve ikinci vurgu hükümetlerin sabit döviz kuru sisteminden vazgeçmemelerinin ve sistemi devam ettirmek istemelerinin bir nedeni olmasına yapılmaktadır. Üçüncü vurgu ise krize neden olan kısırdöngünün meydana gelmesi için sabit döviz kuru rejimini sürdürme maliyetinin, bundan elde edilecek faydaları aştığına dair inancın yaygınlaşması gerektiği üzerinedir (Krugman, 1998). Bu modelin dayandığı en önemli varsayım ekonomi politikalarının ekonomik değişmelere tepki olarak uygulandığı ve ekonomik birimlerin ise beklentilerini oluştururken bunu dikkate aldığıdır (Özer, 1999: 68). İkinci nesil kriz modellerinde finansal krizlerin öngörülemez ve bulaşıcı olduğunu, beklentilerin kendi kendini beslediğini ve bu sürecin krize neden olduğunu, hükümetlerin kur rejimini sürdürme ve terk etme gibi bazı temel konularda seçim yapmak durumunda olduğunu ve makroekonomik göstergelerdeki bozulmanın ve sürü psikolojisiyle hareket etmenin kendi kendini besleyen krizi hızlandırdığını söylemek mümkündür (Akçalı, 2014: 30). İkinci nesil kriz modellerinin öncü göstergeleri ihracat ve ithalat hacmi, reel döviz kuru, yurtiçi reel faiz oran1, endüstriyel üretimdeki azalma, hisse senedi fiyatındaki değişimler, cari işlemler dengesindeki bozulma, kısa dönemli borç miktarı, portföy yatırımları, yurtdışı faiz farklılığı, enflasyondaki artış ile ticaret hadlerindeki kötüleşmedir (Kaminsky, 2003: 21; Avc1 ve Altay, 2013: 49).

1990'ların sonunda, Tayland, Güney Kore, Endonezya, Filipinler ve Malezya dâhil olmak üzere Asya'daki yükselen ekonomilerde bir kriz dalgası şeklinde ortaya çıkan 1997 Asya krizini açıklamada birinci ve ikinci nesil kriz modellerinin yetersiz kalması sonucunda üçüncü nesil kriz modelleri ortaya konulmuştur. Asya krizi sürecinde ikiz krizler olarak da adlandırılan para ve bankacılık krizleri arasındaki etkileşimin birlikte incelendiği görülmektedir. Bankacılık ve para krizlerinin birbirini besleyerek ekonomide bir kısırdöngü medyana getirdiği fikrine dayanan bu modelde krizlerin ülkeler arasında yayılma etkisi Krugman (1998)'in "Hükümetin Ahlaki Risk Yaklaşımı" ve Sachs (1998)'in "Finansal Atak Yaklaşımı" çalışmalarına dayandırılmaktadır. Krugman (1998)'e göre, finans sektöründe en etkili aracı konumunda olan bankaların yükümlülüklerinin açık veya kapalı bir şekilde hükümetler tarafından garanti altına alınması "Ahlaki Risk" sorununa neden olmaktadır. Kârlarını artırmak isteyen bankalar tarafından riskli kredilerin desteklenmesi ve bu şekilde kredi hacminin genişletilmesi finansal aktiflerin değerlerini yükseltmiştir. Böylece finansal sistem aşırı derecede büyümüştür. Bir süre sonra oluşan bu finansal balonların patlaması, süreci tersine çevirmiş ve finansal aktiflerin değerleri düşmüştür. $\mathrm{Bu}$ durum ise ulusal düzeyde ödeme sisteminde bozulmalara ve bankacılık krizlerinin patlak vermesine neden olmuştur. Yaşanan bankac1lık krizleri, para krizlerine neden olmuş ve ikiz kriz eş zamanlı olarak ortaya çıkmıştır.

Üçüncü nesil kriz modellerinde firmaların bilançolarında yaşanan olumsuzlukların nedeni, özellikle döviz cinsinden borçlanan firmaların karşı karşıya kaldıkları kur riski ve net varlıklarının yerli paranın değer kaybetmesiyle kötüleşmesidir. Bu noktada Krugman bilanço etkisinin sadece yükümlülük tarafında değil varlıklar tarafında da söz konusu olacağına dikkat çekmiştir. Özellikle bilânçonun varlıklarını oluşturan kalemlerin değerinin, varlık fiyatları ve onlarla ilgili beklentilere bağlı olarak değişebileceğini; ekonomideki güven eksikliğinin yatırımlarda azalmaya neden olarak varlık fiyatlarındaki gerilemeyi hızlandıracağını işaret etmiştir (Altıntaş ve Öz, 2007: 24). Üçüncü nesil kriz modelleri krizlerin temel özellikleri; aşırı dış borç düzeyi, ahlaki tehlike ve asimetrik bilgi problemleri, finansal kurumların bilanço problemleri, sürü psikolojisi, krizin ülkeler arasında yayılması gibi etkenlere göre çeşitlilik göstermektedir. Bu kriz modellerinin öncü göstergelerine yurtiçi kredi hacmi, M2/rezervler, M2 
çarpanı, banka mevduatı, hisse senedi fiyat1, bankacılık krizleri, sermaye piyasasındaki fiyat hareketleri, bankacılık sektörünün likiditesini yansıtan değişkenler, zayıf bankacılık denetimi, mevduat garantileri, döviz cinsinden aşırı borçlanma, yurtdışı faiz farklılığındaki artış, dış ticaret ve cari işlemler dengesindeki bozulma ile parasal genişleme örnek olarak verilebilir (Kaminsky, 2003: 21; Avc1 ve Altay, 2013: 49).

\section{Literatür Taraması}

1800'lü yıllardan günümüze gelişmiş ya da geri kalmış ülkelerde birçok finansal kriz yaşanmış ve bu krizler ekonomik hayatın bir parçası haline gelmiştir. Farklı coğrafyalarda meydana gelen farklı türdeki krizlerin etkisiyle literatürde finansal kriz göstergelerini incelemeye yönelik çok sayıda çalışmanın yapıldığı görülmektedir. Bu konudaki çalışmaların bir özeti tablo 1'de sunulmuştur.

Tablo 1. Literatür özeti

\begin{tabular}{|c|c|c|c|}
\hline Yazar/Yazarlar & Ülke/Dönem & Yöntem & Bulgular \\
\hline $\begin{array}{l}\text { Eichengreen vd. } \\
\text { (1995) }\end{array}$ & $\begin{array}{l}20 \text { OECD ülkesi/ } \\
1959-1993\end{array}$ & $\begin{array}{l}\text { Çoklu regresyon } \\
\text { ve duyarlılık } \\
\text { analizi }\end{array}$ & $\begin{array}{l}\text { Ulusal paraya yönelik bir spekülatif saldırı, faiz } \\
\text { oranlarının artmasına uluslararası rezervler ile } \\
\text { yurtiçi kredi hacminin azalmasına ve } \\
\text { devalüasyona neden olmaktadır. }\end{array}$ \\
\hline $\begin{array}{l}\text { Frankel ve Rose } \\
\text { (1996) }\end{array}$ & $\begin{array}{l}\text { 100 Gelişmekte } \\
\text { olan ülke/1971- } \\
1992\end{array}$ & Panel veri yöntemi & $\begin{array}{l}\text { Döviz kurunun değerlenmesi, yüksek dış faiz } \\
\text { oranları, doğrudan yabancı yatırımların düşük } \\
\text { kalması, yurtiçi kredilerde artış ve cari } \\
\text { açı/GSYIH oranında yükselme bir ülkenin krize } \\
\text { girme olasıllğını artırmaktadır. }\end{array}$ \\
\hline $\begin{array}{l}\text { Kaminsky ve } \\
\text { Reinhart (1996) }\end{array}$ & $\begin{array}{l}15 \text { Gelişmekte ve } \\
5 \text { Gelişmiş } \\
\text { ülke/1970-1995 }\end{array}$ & Probit modeli & $\begin{array}{l}\text { Para krizlerini öngörmede reel döviz kurunun } \\
\text { değerlenmesi, M1 artışının büyümesi, ihracat ve } \\
\text { ithalatın azalmas1, M2/uluslararas1 rezervlerin } \\
\text { artması, dış ticaret haddinin kötüleşmesi, } \\
\text { uluslararası rezervlerin ve üretimin azalması } \\
\text { öncü göstergeler olarak tespit edilmiştir. }\end{array}$ \\
\hline IMF (1998) & $\begin{array}{l}20 \text { Gelişmiş ve } 30 \\
\text { Gelişmekte olan } \\
\text { ülke/1975-1997 }\end{array}$ & Probit modeli & $\begin{array}{l}\text { Para krizlerinin öncü göstergeleri yurtiçi kredi } \\
\text { hacmindeki genişleme, reel döviz kurunun aşırı } \\
\text { değerlenmesi, hisse senedi fiyatındaki düşus, } \\
\text { düşük yurt içi reel faiz oranları, ticaret hadlerinin } \\
\text { bozulması, M2'nin uluslararası rezervlere } \\
\text { oranındaki büyüme ve dünya reel faiz oranındaki } \\
\text { artışlar olarak tespit edilmiştir. }\end{array}$ \\
\hline $\begin{array}{l}\text { Kaminsky vd. } \\
\text { (1998) }\end{array}$ & $\begin{array}{l}15 \text { Gelişmiş ve } 5 \\
\text { Gelişmekte olan } \\
\text { ülke/1970-1995 } \\
\text { aylık veriler }\end{array}$ & Sinyal yaklaşımı & $\begin{array}{l}\text { Krizi açıklamada en anlamlı göstergeler olarak, } \\
\text { çıtı düzeyi, ihracat, uluslararası rezervler, M1, } \\
\text { borsa endeksi, M2'nin uluslararası rezervlere } \\
\text { oranı ve reel döviz kuru bulunmuştur. }\end{array}$ \\
\hline $\begin{array}{l}\text { Berg ve Pattillo } \\
\text { (1998) }\end{array}$ & $\begin{array}{l}\text { 25 Gelişmekte } \\
\text { olan } \\
\text { ülke/1995:Q5- } \\
\text { 1997:Q12, } \\
\text { 1970:Q1-1995:Q4 }\end{array}$ & $\begin{array}{l}\text { Sinyal yaklaşımı } \\
\text { ve probit modeli }\end{array}$ & $\begin{array}{l}\text { Para krizlerini açıklamada M1, reel döviz } \\
\text { kurunun trendden sapması, yurtiçi } \\
\text { krediler/GSYIH, M2'nin uluslararası rezervlere } \\
\text { oranı, uluslararası rezervler, ticaret hadleri, } \\
\text { ihracatın büyüme oranı ve reel faiz oranı anlamlı } \\
\text { sonuç veren göstergeler olmuştur. }\end{array}$ \\
\hline $\begin{array}{l}\text { Lau ve Yan } \\
(2002)\end{array}$ & 16 ülke/1981-2001 & Logit model & \begin{tabular}{llr}
\multicolumn{3}{l}{ Spekülatif ataklar için kamu açıkları, reel döviz } \\
kuru değerlenme ve k1sa vadeli & yabanc1 \\
yükümlülükler/toplam & uluslararası & rezervler \\
değişkenleri anlamlı & tahminciler & olarak \\
belirlenmiştir. & & \\
\end{tabular} \\
\hline Oka (2003) & $\begin{array}{l}118 \text { ülke/1980- } \\
1997\end{array}$ & $\begin{array}{l}\text { Sinyal yaklaşımı } \\
\text { ve probit modeli }\end{array}$ & $\begin{array}{l}\text { Para krizine yakalanma riskinin rezervlerin } \\
\text { ithalata oranı düşük olan, IMF'e yüksek borcu } \\
\text { bulunan, borç servisinin ihracata oranı yüksek } \\
\text { olan ve ihracat artışı yavaşlayan ülkelerde daha } \\
\text { yüksek olduğu bulunmuştur. }\end{array}$ \\
\hline $\begin{array}{l}\text { Mariano vd. } \\
\text { (2004) }\end{array}$ & $\begin{array}{l}\text { Türkiye/1954:Q1- } \\
\text { 2002:Q10 }\end{array}$ & $\begin{array}{l}\text { Markow Regime } \\
\text { Switching model }\end{array}$ & $\begin{array}{l}\text { Yurtiçi kredi mevduat oranı, reel döviz kuru ve } \\
\text { döviz rezervleri, finansal kırılganlığın en önemli } \\
\text { belirleyicileri olarak bulunmuştur. }\end{array}$ \\
\hline
\end{tabular}




\begin{tabular}{|c|c|c|c|}
\hline Tosuner (2005) & $\begin{array}{l}\text { Türkiye/1991:Q7- } \\
\text { 2004:Q5 }\end{array}$ & Sinyal yaklaşımı & $\begin{array}{l}\text { Net uluslararası Rezervler/ithalat, M2/GSYİH, } \\
\text { mevduat bankalarının özel yurtiçi } \\
\text { kredileri/GSYIH, reel kur İhracat/ithalat, cari } \\
\text { denge/GSYİH, portföy/GSYIH, ve ABD-Türkiye } \\
\text { reel faiz fark1 değişkenleri krizi öngörmede etkili } \\
\text { bulunmuştur. }\end{array}$ \\
\hline $\begin{array}{l}\text { Altıntaş ve Öz } \\
\text { (2007) }\end{array}$ & $\begin{array}{l}\text { Türkiye/1990- } \\
2005 \text { üçer aylık }\end{array}$ & Sinyal yaklaşımı & $\begin{array}{l}\text { Para krizini açıklamada anlamlı bulunan } \\
\text { göstergeler M2/ rezervler, sanayi üretim endeksi, } \\
\text { üretim artış1 (sabit fiyatlarla), sermaye çıkış1, } \\
\text { reel efektif döviz kuru, GSMH (1987 sabit } \\
\text { fiyatlarla), , M1, İMKB } 100 \text { endeksi ve } 3 \text { aylık } \\
\text { mevduat faizi olmuştur. }\end{array}$ \\
\hline $\begin{array}{l}\text { Kaya ve Y1lmaz } \\
(2007)\end{array}$ & $\begin{array}{l}\text { Türkiye/2003:Q1- } \\
\text { 2005:Q12 }\end{array}$ & $\begin{array}{l}\text { Sinyal yaklaşımı } \\
\text { ve Logit modeli }\end{array}$ & $\begin{array}{l}\text { Para krizini öngörmede etkili olan değişkenler } \\
\text { k1sa vadeli dış borçlar, M2Y, bütçe dengesi ve } \\
\text { diş ticaret hadlerinin GSMH'ya oranları ile reel } \\
\text { döviz kuru değerlenmesi olarak belirlenmiştir }\end{array}$ \\
\hline $\begin{array}{l}\text { Çeşmeci ve } \\
\text { Önder (2008) }\end{array}$ & $\begin{array}{l}\text { Türkiye/1992:Q2- } \\
\text { 2004:Q10 }\end{array}$ & $\begin{array}{l}\text { Sinyal yaklaşımı, } \\
\text { yapısal model ve } \\
\text { Markow Switching } \\
\text { modeli }\end{array}$ & $\begin{array}{l}\text { Reel sektör güven endeksi, para piyasası bask1 } \\
\text { endeksi ve kamu sektörü değişkenleri finansal } \\
\text { krizleri öngörmede anlamlı bulunmuş ve Nisan } \\
1994 \text {, Kasım } 2000 \text { ve Şubat } 2001 \text { krizleri başarı } \\
\text { ile öngörülmüştür. }\end{array}$ \\
\hline $\begin{array}{l}\text { Avc1 ve Altay } \\
\text { (2013) }\end{array}$ & $\begin{array}{l}\text { Türkiye/1991:Q1- } \\
\text { 2009:Q7 } \\
\text { Arjantin/1992:Q1- } \\
\text { 2010:Q12 } \\
\text { Tayland/1990:Q1- } \\
\text { 2009:Q8 } \\
\text { İngiltere/1990:Q1- } \\
\text { 2010:Q12 }\end{array}$ & Sinyal yaklaşımı & $\begin{array}{l}\text { Türkiye için, reel faiz oranı farklılığ } 1 \text {, reel döviz } \\
\text { kurunun trendden sapması, hisse senedi fiyat1, } \\
\text { para piyasas bask1 endeks ve yurtiçi } \\
\text { krediler/endüstriyel üretim; Tayland için } \\
\text { enflasyon, yurtiçi krediler/endüstriyel üretim, } \\
\text { para piyasas1 bask1 endeksi ve ticaret haddi; } \\
\text { Arjantin için ticaret dengesi, endüstriyel üretim, } \\
\text { reel faiz oranı farkl1lığ1, M2/rezervler ve para } \\
\text { piyasası bask1 endeksi; İngiltere için enflasyon, } \\
\text { reel döviz kurunun trendden sapmas, yurtiçi } \\
\text { krediler/endüstriyel üretim ve endüstriyel üretim } \\
\text { finansal krizleri öngörmede en başarılı } \\
\text { değişkenler olarak tespit edilmiştir. }\end{array}$ \\
\hline $\begin{array}{l}\text { Caprio Jr. vd. } \\
\text { (2014) }\end{array}$ & 83 ülke/1998-2006 & $\begin{array}{l}\text { Yatay kesit ve } \\
\text { bankalar arası } \\
\text { (cross-bank) analiz }\end{array}$ & $\begin{array}{l}\text { Daha yüksek kredi mevduat oranına sahip } \\
\text { ülkelerin krize maruz kalma olasılığ } 1 \text { yüksek } \\
\text { çıkmış ve banka düzeyinde yapılan analizler bu } \\
\text { sonuçları pekiştirmiştir. }\end{array}$ \\
\hline Ascarya (2017) & $\begin{array}{l}\text { Endonezya/2004:Q } \\
\text { 3-2012:Q6 }\end{array}$ & $\begin{array}{l}\text { Vektör hata } \\
\text { düzeltme modeli }\end{array}$ & $\begin{array}{l}\text { Finansal krizin gerçek belirleyicilerinin } \\
\text { istikrarsız para sistemi (faiz sistemi ve yasal para } \\
\text { sistemi), zayıf yönetişim (yönetilen fiyat) ve } \\
\text { sürdürülemez mali sistem (değişken gida) ile } \\
\text { ekonomik aktörlerin yanlış davranışı (beklenti) } \\
\text { şeklinde yapısal olduğu tespit edilmiştir. }\end{array}$ \\
\hline
\end{tabular}

\section{Yöntem}

Türkiye 1994:01-2018:11 dönem aralığında finansal krizler yaşamış olduğu için finansal krizlerin oluşturduğu kriz göstergelerinin değerlendirilmesi oldukça önemlidir. Bu nedenle çalışmada finansal krizler için gösterge niteliği taşıyabilecek ve ekonomi literatüründe sıklıkla kullanılan bütçe açığının GSYİH'ya oranı, cari açığın GSYİH'ya oranı, enflasyon oranı, faiz oranı, kapasite kullanım oranı, TCMB döviz varlıkları, döviz kuru, ithalat, para arzı ve sanayi üretim endeksi değişkenleri kullanılarak bir model oluşturmak amaçlanmıştır. Çalışmada kullanılacak olan bağımsız değişkenler sözü geçen finansal kriz göstergelerinden oluşmakta olup bağımlı değişken için kukla değişken oluşturulması gerekli olmuştur. Bunun nedeni kriz dönemlerinin "kriz var" veya "kriz yok" ikili tercihini yansitan bir zaman serisi ile ifade edilme zorunluluğudur.

Çalışmada kullanılan finansal kriz bağımlı değişkeni 1 ve 0 değerleri ile ifade edildiği için ekonometrik model tahmini doğrusal olasilik, logit, probit veya tobit analizlerinde biri ile yapılmak durumundadır (Gujarati, 1999: 540). Finansal kriz tahminlerinde doğrusal olmamas1 
nedeniyle probit modelinin tercih edildiği görülmektedir. Bunun temel nedenlerinden biri doğrusal modellerde değişken değişimlerinin her birim için aynı etkiye sahip olmasıdır (Sezgin ve Özdamar, 2010: 240). Araştırılacak bağımlı değişkenin kesik formlu yapıda olması çalışmada Probit analizinden yararlanılmasında belirleyici olmuştur. Bununla birlikte probit modelde normal birikimli dağılım fonksiyonunun kullanılması modelin ayırt edici özelliğini oluşturmakta ve kriz analizleri için daha sağlıklı sonuçlar elde edilmesini sağlamaktadır.

Bağımlı değişkenin kategorik formda, başka bir ifadeyle "başarılı-başarısız", "var-yok" şeklinde olması durumunda oluşturulan regresyon modellerinde sıklıkla kullanılan bir yöntem Probit regresyon analizidir. Bu yöntemde bağımsız değişkenlerin nitel ya da nicel olmasında herhangi bir sakınca yokken, bağımlı değişkenin nitel olma zorunluluğu ön plana çıkmaktadır (Gujarati,1988: 705).

Literatürde "Normit Model" olarak da anılan probit analizi, doğrusal olasıllı modeline alternatif olarak geliştirilen bir yöntemdir (Gujarati, 1995: 608). Özellikle finansal kriz tahminleri açısından doğrusal olasılık modeline göre bazı avantajlara sahip olması modelin tercih edilebilirliğinin artmasına neden olmuştur. Öyle ki doğrusal olasılık modelinde, bağımlı değişken olasıllı değerleri belirlenirken 0'dan küçük değerler 0'a, 1'den büyük değerler ise 1'e eşitlenerek çıkarım yapılmaktadır. Bu da 0 ile 1 arasında bir değerin konu edilememesi anlamına gelmektedir. Doğrusal nitelikte olmayan Probit modeli ise normal birikimli dağılım fonksiyonunun tersi alınarak doğrusal hale getirilmekte ve böylece modele ait olasıllk değeri 0 ve 1 arasında bir değer ile ifade edilebilmektedir (Gujarati, 1988: 707-708). İki seçenekli formu olan bağımlı değişkenler incelenirken kullanılabilen analiz, fayda teorisine dayanan bir modelleme olup gözlenemeyen bir fayda endeksine bağlı olduğu varsayılan bir durumu açıklamak üzere tasarlanmıştır. Söz konusu endeks, bağımsız değişkene göre belirlenmekte ve bağımlı değişkenin olabilirlik ihtimalini açıklama gücü büyüklüğü ile doğru orantılı olarak oluşmaktadır (Akın, 2002: 38).

Probit modelinin temel varsayımı, gözlemlenebilen $X_{i}$ açıklayıcı değişken ve gözlemlenemeyen $\mathrm{Y}_{\mathrm{i}}$ bağımlı değişkenini içeren $Y_{i}^{*}=\sum \beta_{k} \mathrm{X}_{i k}+\varepsilon_{i}$ formunda bir yanıt fonksiyonuna dayanmaktadır. Modellemedeki hata terimlerinin sifır ortalama ile simetrik bir dağılıma ve x değerleri arasında sabit varyansa sahip olan bağımsız rasgele değişkenler olduğu varsayılmaktadır. Analizde bağımsız değişkene göre belirlenen ve genellikle sıfır olduğu varsayılan bir eşik değer (c) kullanılmaktadır (Demaris, 2004: 251).

Bu kapsamda probit modeli (1) nolu denklem ile ifade edilmektedir:

$$
P(y=1)=\varnothing\left(X_{i} \beta\right)=\int_{-\infty}^{X_{i} \beta} \frac{1}{\sqrt{2 \pi}} \exp \left(\frac{-z^{2}}{2}\right) \mathrm{d} z
$$

Yukarıda yer alan denklemde, $\varnothing$ (.) ifadesi olasılık değerinin 0 -1 veya $\lim _{z \rightarrow+\infty} \varnothing(z)=$ 1 ve $\lim _{z \rightarrow+\infty} \emptyset(z)=0$ arasında olmasinı temin eden kısıt faktörüdür (Johnston ve Dinardo, 1997: 418; Train, 2003: 20). " $\mathrm{X}_{\mathrm{i}} \beta$ " ile ifade edilen probit indeksindeki $\beta$ değeri probit model katsayısıdır. Bu katsayı, tahminlenmiş modelde yer alan birimlik artışın indeks değerinde yapacağı $\beta$ standart sapma düzeyindeki artışı temsil etmektedir (Kayış, 2008: 301). Bu çerçevede elde edilen tahmin modeli bağımsız değişkenlerin kategorik bağımlı değişken üzerindeki etkisinin katsayı olarak yorumlanmasına imkân vermemekte, değişkenlerin etki düzeyini değil olasılık düzeyindeki etki yönünü tahminlemektedir. Bu nedenle, probit analizinde ek olarak marjinal etki hesaplaması yapılması gerekmektedir.

Probit model ile tanımlanan herhangi bir fonksiyonun marjinal etki hesaplaması, (2) nolu denklemdeki gibi ifade edilmektedir (Baltagi, 1997: 335):

$$
\partial \varnothing\left(X_{i}^{\prime} \beta\right) / \partial X_{k}=\emptyset_{i} \beta_{k}
$$

Eşitliğe göre, tahminlenen marjinal etkiler ve olasılık tutarlı olduğu gibi asimtotik etkindir. Bunun nedeni modelin değişmeyen varyans özelliğine sahip olmasıdır (Knapp ve Seaks, 1992: 406). 


\section{Bulgular}

Analizde kullanılan değişkenler 1994:01-2018:11 dönemi aylık verilerini kapsayan finansal kriz göstergeleri ile bağımlı finansal kriz kukla değişkeni arasındaki ilişkinin incelenmesi amacıyla her bir değişkenin kriz üzerindeki olasılık etkisini ortaya koymak amacıyla oluşturulan Probit analizleri kullanılmıştır. Söz konusu bağımsız değişkenlerden bütçe açığının GSYİH'ya oranı ve cari açığın GSYİH'ya oranını temsil edecek olan değişkenler Türkiye için aylı GSYİH verilerinin bulunmaması nedeniyle sanayi üretim endeksi kullanılarak türetilmiştir. İlgili türetme işlemi bütçe açığı ve cari açık serilerinin endekse dönüştürülüp sanayi üretim endeksine oranlanması yoluyla elde edilmiştir. Ayrıca döviz kuru ve sanayi üretim endeksi serilerine baz yıl değişikliğinden kaynaklanan uyumsuzlukların giderilmesi amacıyla gerekli dönüşüm işlemleri uygulanmıştır. Enflasyon oranı değişkeni ise baz yıl uyarlama işlemleri yapılmış olan Tüketici Fiyat Endeksi serisi kullanılarak türetilmiştir. Analizde kullanılan tüm veri setine Türkiye Cumhuriyeti Merkez Bankası Elektronik Veri Dağıtım Sistemi (EVDS) tabanından ulaşılmış olup değişkenlerden TCMB döviz varlıkları, döviz kuru, ithalat ve para arzı değişkenleri logaritmik formda denkleme dâhil edilmişlerdir. Bu kapsamda, Tablo 2'de çalışmada kullanılan açıklayıcı değişkenlere iliş̧in tanımlamalar ve istatistiki gösterge değerlerine yer verilmiştir.

Tablo 2. Veri tanımlamaları ve istatistiki göstergeler

\begin{tabular}{|c|c|c|c|c|c|}
\hline \multicolumn{2}{|c|}{ Veriler } & \multicolumn{4}{|l|}{ Açıklama } \\
\hline \multicolumn{2}{|c|}{ BA } & \multicolumn{4}{|c|}{ BÜTÇE AÇIĞI ENDEKS / SANAYİ ÜRETIMM ENDEKSİ } \\
\hline \multicolumn{2}{|c|}{$\mathrm{CA}$} & \multicolumn{4}{|c|}{ CARİ AÇIK ENDEKS / SANAYİ ÜRETIMM ENDEKSİ } \\
\hline \multicolumn{2}{|c|}{ ENF } & \multicolumn{4}{|c|}{ ENFLASYON ORANI-TÜFE BAZLI } \\
\hline \multicolumn{2}{|c|}{ FAİZ } & \multicolumn{4}{|c|}{ MEVDUATLARA UYGULANAN AZAMİ FAİZ ORANLARI (\%) } \\
\hline \multicolumn{2}{|c|}{ KKO } & \multicolumn{4}{|c|}{ KAPASİTE KULLANIM ORANI } \\
\hline \multicolumn{2}{|c|}{ LDOVİZ } & \multicolumn{4}{|c|}{ TCMB DÖVİZ VARLIKLARI (ABD Doları) } \\
\hline \multicolumn{2}{|c|}{ LKUR } & \multicolumn{4}{|c|}{ REEL EFEKTIFF DÖVİZ KURU-TÜFE BAZLI } \\
\hline \multicolumn{2}{|c|}{ LM } & \multicolumn{4}{|c|}{ İTHALAT (ABD Doları) } \\
\hline \multicolumn{2}{|c|}{ LM2 } & \multicolumn{4}{|c|}{ M2 PARA ARZI (ABD Doları) } \\
\hline \multicolumn{2}{|c|}{ SUE } & \multicolumn{4}{|c|}{ SANAYİ ÜRETIM ENDEKSİ } \\
\hline \multicolumn{6}{|c|}{ Serilere Ait İstatistiksel Göstergeler } \\
\hline Seriler & Gözlem & Ortalama & Std. Sapma & Minimum & Maksimum \\
\hline BA & \multirow{10}{*}{299} & 638.724 & 1349.115 & -3073.549 & 5863.695 \\
\hline CA & & 2.898 & 3.198 & -3.033 & 13.873 \\
\hline ENF & & 0.021 & 0.025 & -0.015 & 0.221 \\
\hline FAİZ & & 35.333 & 27.594 & 9.900 & 107.560 \\
\hline KKO & & 78.218 & 4.551 & 60.800 & 88.923 \\
\hline LDOVİZ & & 10.641 & 0.818 & 8.100 & 11.646 \\
\hline LKUR & & 4.575 & 0.165 & 4.071 & 4.850 \\
\hline LM & & 9.016 & 0.776 & 7.210 & 10.012 \\
\hline LM2 & & 18.639 & 2.243 & 12.968 & 21.456 \\
\hline SUE & & 65.076 & 25.451 & 29.318 & 129.990 \\
\hline
\end{tabular}


Analizde kullanılan gösterge değişkenlerin 1994:01-2018:11 dönemine ait zaman yolu grafikleri aşağıdaki şekildedir.

Sekil 1. Değişkenlerin zaman yolu grafikleri
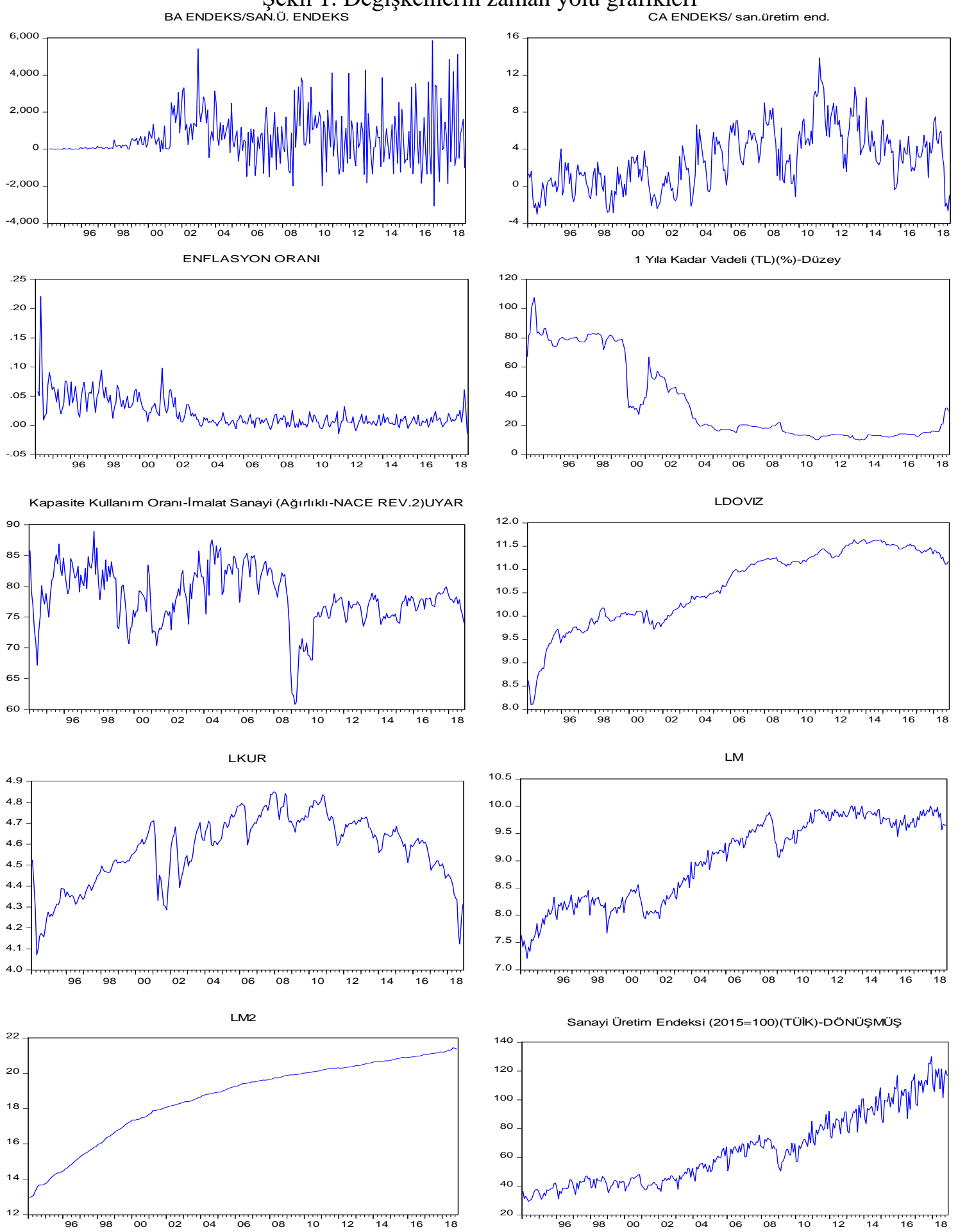

Probit regresyon analizinde bağımlı kukla değişkenin olasılık tahmini için kullanılacak olan bağımsız değişkenlerin analize dahil edilmeden önce durağanlık seviyelerinin belirlenmesi ve analize hazır hale getirilmesi gerekmektedir (Cebeci, 2012: 139). Bu sebeple önsel yorumu Şekil 1'de sunulan grafikler ile de yapılabilecek olan durağanlık seviyelerinin belirlenmesi için ADF (Genişletilmiş Dickey-Fuller) durağanlık analizinden yararlanılmış ve analizde Akaike 
(AIC) bilgi kriteri esas alınmıştır. Söz konusu analiz sonucunda ulaş1lan sonuçlar Tablo 3'de belirtilmiştir.

Tablo 3. ADF durağanlık analizi sonuçları

\begin{tabular}{|c|c|c|c|c|c|c|}
\hline \multirow[b]{2}{*}{ Değişken } & \multicolumn{2}{|c|}{ ADF (Sabitsiz) } & \multicolumn{2}{|c|}{ ADF (Sabitli) } & \multicolumn{2}{|c|}{ ADF (Sabitli ve Trendli) } \\
\hline & Düzey & 1. Fark & Düzey & 1. Fark & Düzey & 1. Fark \\
\hline $\mathbf{B A}$ & $\begin{array}{c}-1.0251 \\
(0.2745) \\
\end{array}$ & $\begin{array}{c}-11.23622^{\mathrm{a}} \\
(0.0000)\end{array}$ & $\begin{array}{c}-2.2247 \\
(0.1980) \\
\end{array}$ & $\begin{array}{c}-11.2318^{\mathrm{a}} \\
(0.0000)\end{array}$ & $\begin{array}{c}-2.2517 \\
(0.4586) \\
\end{array}$ & $\begin{array}{c}-11.2114^{\mathrm{a}} \\
(0.0000)\end{array}$ \\
\hline CA & $\begin{array}{l}-1.7015 \\
(0.0842) \\
\end{array}$ & $\begin{array}{l}-4.6072^{a} \\
(0.0000)\end{array}$ & $\begin{array}{l}-2.8090 \\
(0.0582) \\
\end{array}$ & $\begin{array}{c}-4.5762^{a} \\
(0.0002) \\
\end{array}$ & $\begin{array}{l}-2.9351 \\
(0.1531) \\
\end{array}$ & $\begin{array}{c}-4.6282^{a} \\
(0.0011)\end{array}$ \\
\hline ENF & $\begin{array}{c}-2.6344 \\
(0.0084) \\
\end{array}$ & $\begin{array}{l}-7.45188^{a} \\
(0.0000)\end{array}$ & $\begin{array}{c}-2.6080 \\
(0.0925) \\
\end{array}$ & $\begin{array}{l}-7.5454^{a} \\
(0.0000)\end{array}$ & $\begin{array}{c}-2.1207 \\
(0.5316) \\
\end{array}$ & $\begin{array}{c}-7.7589^{a} \\
(0.0000)\end{array}$ \\
\hline FAİZ & $\begin{array}{l}-2.3728 \\
(0.0173)\end{array}$ & $\begin{array}{l}-5.4152^{a} \\
(0.0000)\end{array}$ & $\begin{array}{c}-1.8156 \\
(0.3725) \\
\end{array}$ & $\begin{array}{c}-5.61311^{\mathrm{a}} \\
(0.0000)\end{array}$ & $\begin{array}{c}-0.1840 \\
(0.9931) \\
\end{array}$ & $\begin{array}{l}-5.9623^{a} \\
(0.0000)\end{array}$ \\
\hline KKO & $\begin{array}{c}-0.4183 \\
(0.5319) \\
\end{array}$ & - & $\begin{array}{r}-3.2616 \\
(0.0176) \\
\end{array}$ & - & $\begin{array}{c}-3.8055^{b} \\
(0.0176)\end{array}$ & - \\
\hline LDOVİz & $\begin{array}{c}1.3235 \\
(0.9533) \\
\end{array}$ & $\begin{array}{c}-4.7549^{\mathrm{a}} \\
(0.0000)\end{array}$ & $\begin{array}{l}-2.1331 \\
(0.2319) \\
\end{array}$ & $\begin{array}{c}-5.4127^{\mathrm{a}} \\
(0.0000)\end{array}$ & $\begin{array}{c}-1.2992 \\
(0.8860) \\
\end{array}$ & $\begin{array}{c}-5.7316^{a} \\
(0.0000) \\
\end{array}$ \\
\hline LKUR & $\begin{array}{c}0.1215 \\
(0.7202) \\
\end{array}$ & $\begin{array}{l}-7.0671^{a} \\
(0.0000)\end{array}$ & $\begin{array}{l}-1.7105 \\
(0.4249) \\
\end{array}$ & $\begin{array}{c}-7.0554^{a} \\
(0.0000)\end{array}$ & $\begin{array}{c}-0.2013 \\
(0.9928) \\
\end{array}$ & $\begin{array}{c}-7.6671^{a} \\
(0.0000)\end{array}$ \\
\hline $\mathbf{L M}$ & $\begin{array}{c}1.2944 \\
(0.9506) \\
\end{array}$ & $\begin{array}{l}-5.0253^{\mathrm{a}} \\
(0.0000) \\
\end{array}$ & $\begin{array}{c}-1.3836 \\
(0.5904) \\
\end{array}$ & $\begin{array}{c}-5.3201^{\mathrm{a}} \\
(0.0000) \\
\end{array}$ & $\begin{array}{l}-1.6457 \\
(0.7724) \\
\end{array}$ & $\begin{array}{l}-5.4141^{\mathrm{a}} \\
(0.0000)\end{array}$ \\
\hline LM2 & $\begin{array}{c}0.8572 \\
(0.8945) \\
\end{array}$ & - & $\begin{array}{r}-8.2452^{a} \\
(0.0000) \\
\end{array}$ & - & $\begin{array}{r}-4.93488^{\mathrm{a}} \\
(0.0000)\end{array}$ & - \\
\hline SUE & $\begin{array}{c}2.0327 \\
(0.9902) \\
\end{array}$ & $\begin{array}{l}-3.3034^{a} \\
(0.0010)\end{array}$ & $\begin{array}{c}0.0526 \\
(0.9615) \\
\end{array}$ & $\begin{array}{c}-3.9983^{\mathrm{a}} \\
(0.0016)\end{array}$ & $\begin{array}{c}-2.1843 \\
(0.4960) \\
\end{array}$ & $\begin{array}{c}-4.2618{ }^{\mathrm{a}} \\
(0.0041)\end{array}$ \\
\hline
\end{tabular}

Not: $a$ ve $b$ üst indisleri parametre tahminlerinin sırasıla $\% 1$ ve $\% 5$ düzeyinde anlamlı olduğunu, parantez içerisinde belirtilen ifadeler ise olasılık değerlerini göstermektedir.

Tablo 3'te sunulan sonuçlar incelendiğinde kapasite kullanım oranı ve para arzı değişkenlerinin seviyesinde, diğer serilerin tamamının ise birinci farkında durağanlaştıkları görülmektedir. Probit modellemelerinde bağımlı değişken olarak incelenecek olan finansal kriz değişkeni ise Kaminsky vd. (1998) tarafından ifade edilen KLR modeli esas alınarak oluşturulmuştur. $\mathrm{Bu}$ kapsamda finansal kriz dönemlerinin tespiti amaciyla finansal bask1 endeksi (FBE) kullanılmıştır. KLR modelinde finansal kriz tanımlamasında yararlanılacak olan FBE hesaplamasına değinilmiştir. Söz konusu endeks, döviz kuru, faiz oranı ve resmi döviz rezervlerinde meydana gelen yüzde değişimlerin ortalamasından yola çıkılarak hesaplanmaktadır. Ayrıca değişkenlerin standart hale getirilmesi gerekmektedir. Bu çerçevede FBE hesaplaması aşağıdaki şekilde yapılmaktadır (Kaminsky vd., 1998):

$$
\mathrm{FBE}=[\text { Nominal Döviz Kuru Değişimi (\%)] + [Faiz Oranı Değişimi (\%)] }
$$

$$
\text { - [Brüt Rezervlerdeki Değişim(\%)] }
$$

Hesaplamada $\mu$ ortalamayı, $\sigma$ ise standart sapmayı ifade etmek üzere ve ortalamanın sıfir olduğu varsayımı altında $\mathrm{FBE} \geq \mu+1.5 \sigma$ sonucunu veren dönemlerde krizin varlığı kabul edilir. Başka bir ifadeyle hesaplanan endeks değerinin FBE'nin standart sapmasının 1.5 katına eşit veya daha fazla olması krizin varlığına işaret eder (Uygur, 2001: 8). Bu çalışma için de benzer şekilde ilgili değişkenlere standartlaştırma işlemi yapılarak FBE hesaplaması gerçekleştirilmiş ve kukla değişken bu şekilde elde edilmiş̧ir. Ayrıca oluşturulan tüm probit modellerinde, katsayı kovaryansları gözlemlenen Huber-White kriteri ve maksimum likelihood değeri ise Quadratic Hill Climbing algoritması kullanılarak hesaplanmıştır. Uygun model tahmin aşamasında tama yakın çoklu doğrusallık nedeniyle çoklu model kullanılması yoluna gidilmiştir. Bu kapsamda bağımsız değişkenler arasında çoklu doğrusal bağıntıya sebep olmamak için 4 adet probit modeli tahmin edilmiştir. Bu durumun temel sebebi ise temel makroekonomik göstergelerin birbirlerini etkiyerek modelin işleyişini bozmasıdır. Dolayısıyla türetilen çeşitli varyasyon sonuçlarına göre BA değişkeni model dışı bırakılmak zorunda 
kalınmıştır. Bu kapsamda elde edilen probit modeline ait sonuçlar aşağıda sırasıyla rapor edilmiştir.

Tablo 4. Probit 1. Model tahmin sonuçları

\begin{tabular}{ccccccc}
\hline \multicolumn{7}{c}{ BAĞIMLI DEĞIŞKEN: Kriz Kukla } \\
\hline Değişken & Katsayı & Std. Hata & z-İstatistiği & Olasılık Değeri & \%95 Coenf. İnterval \\
\hline C & -6.5385 & 2.3535 & -2.7782 & 0.0055 & -11.1705 & -1.9065 \\
\hline CA & -0.1950 & 0.0872 & -2.2360 & 0.0253 & -0.3667 & -0.0234 \\
\hline ENF & 27.6365 & 9.2939 & 2.9736 & 0.0029 & 9.3450 & 45.928 \\
\hline LDOVIZ & -15.6408 & 3.1734 & -4.9288 & 0.0000 & -21.8864 & -9.3952 \\
\hline LM2 & 0.2155 & 0.1139 & 1.8915 & 0.0586 & -0.0087 & 0.4397 \\
\hline McFadden R ${ }^{2}$ & 0.4693 & LR İstatistiği & & 50.1052 & & \\
\hline Log likelihood & -28.3328 & Prob (LR) & & 0.0000 & & \\
\hline Wald F-İstatistiği & 9.9262 & LM Test & & 0.1409 & \\
\hline Prob (Wald F) & 0.0000 & Prob (LM) & & 0.7074 & \\
\hline
\end{tabular}

Fonksiyon Denklemi: Z=-6.5385-0.1950*CA+27.6365*ENF-15.6408*LDOVIZ+0.2155*LM2

Tablo 5. Probit 2. model tahmin sonuçları

\begin{tabular}{|c|c|c|c|c|c|c|}
\hline \multicolumn{7}{|c|}{ BAĞIMLI DEĞİŞKEN: Kriz Kukla } \\
\hline Değişken & Katsayı & Std. Hata & z-İstatistiği & Olasılık Değeri & $\% 95 \mathrm{Coe}$ & İnterval \\
\hline C & 8.2881 & 3.0267 & 2.7383 & 0.0062 & 2.3313 & 14.2450 \\
\hline FAIZ & 0.8176 & 0.1400 & 5.8402 & 0.0000 & 0.5421 & 1.0932 \\
\hline KKO & -0.1542 & 0.0434 & -3.5540 & 0.0004 & -0.2396 & -0.0688 \\
\hline LDOVIZ & -11.0240 & 3.2795 & -3.3614 & 0.0008 & -17.4784 & -4.5695 \\
\hline LKUR & -23.9153 & 8.4863 & -2.8181 & 0.0048 & -40.6171 & -7.2136 \\
\hline McFadden $\mathbf{R}^{2}$ & 0.7930 & $\begin{array}{c}\text { LR } \\
\text { İstatistiği } \\
\end{array}$ & & -11.688 & & \\
\hline Log likelihood & 89.5799 & Prob (LR) & & 0.0000 & & \\
\hline Wald F-İstatistiği & 8.7660 & LM Test & & 1.3682 & & \\
\hline Prob (Wald F) & 0.0000 & Prob $(\mathbf{L M})$ & & 0.2421 & & \\
\hline
\end{tabular}

Fonksiyon Denklemi: Z= 8.2881+0.8176*FAİZ-0.1542*KKO-11.0240*LDOVIZ-23.9153*LKUR

Tablo 6. Probit 3. model tahmin sonuçları

\begin{tabular}{ccccccc}
\hline \multicolumn{7}{c}{ BAĞIMLI DEĞIŞKEN: Kriz Kukla } \\
\hline Değişken & Katsayı & Std. Hata & z-İstatistiği & Olasılık Değeri & \%95 Coenf. İnterval \\
\hline C & -3.3667 & 0.5369 & -6.2702 & 0.0000 & -4.4235 & -2.3100 \\
\hline FAIZ & 0.7406 & 0.1077 & 6.8786 & 0.0000 & 0.5287 & 0.9525 \\
\hline LDOVIZ & -7.7508 & 2.4797 & -3.1256 & 0.0018 & -12.6310 & -2.8706 \\
\hline LKUR & -19.8441 & 7.2838 & -2.7244 & 0.0064 & -34.1793 & -5.5089 \\
\hline SUE & -0.0601 & 0.0300 & -2.0041 & 0.0451 & -0.1192 & -0.0011 \\
\hline McFadden R ${ }^{2}$ & 0.7737 & LR İstatistiği & & 87.3968 & & \\
\hline Log likelihood & -12.7800 & Prob (LR) & & 0.0000 & & \\
\hline Wald F-İstatistiği & 12.4286 & LM Test & & 0.0059 & \\
\hline Prob (Wald F) & 0.0000 & Prob (LM) & & 0.9388 & \\
\hline
\end{tabular}

Fonksiyon Denklemi: Z= -3.3667+0.7406*FAİZ -7.7508*LDOVIZ-19.8441*LKUR-0.0601*SUE 
Tablo 7. Probit 4. model tahmin sonuçları

\begin{tabular}{ccccccc}
\hline & \multicolumn{7}{c}{ BAĞIMLI DEĞİSKEN: Kriz Kukla } & & \\
\hline Değişken & Katsayı & Std. Hata & z-İstatistiği & Olasılık Değeri & \%95 Coenf. İnterval \\
\hline C & -3.3079 & 0.5795 & -5.7079 & 0.0000 & -4.4485 & -2.1673 \\
\hline FAIZ & 0.6746 & 0.1031 & 6.5431 & 0.0000 & 0.4717 & 0.8775 \\
\hline LDOVIZ & -8.8807 & 2.8496 & -3.1163 & 0.0018 & -14.4893 & -3.2722 \\
\hline LKUR & -18.7819 & 7.3497 & -2.5555 & 0.0106 & -33.2468 & -4.3169 \\
\hline LM & -3.4318 & 1.9189 & -1.7884 & 0.0737 & -7.2084 & 0.3448 \\
\hline McFadden R $\mathbf{R}^{\mathbf{2}}$ & 0.7716 & LR İstatistiği & & 87.1607 & & \\
\hline Log likelihood & -12.8980 & Prob (LR) & & 0.0000 & & \\
\hline Wald F-İstatistiği & 11.1996 & LM Test & & 0.5769 & & \\
\hline Prob (Wald F) & 0.0000 & Prob (LM) & & 0.4475 & \\
\hline
\end{tabular}

Fonksiyon Denklemi: Z= -3.3079+0.6746*FAİZ -8.8807*LDOVIZ-18.7819*LKUR-3.4318*LM

Yukarıda raporlanan sonuçlar incelendiğinde ortak değişkenlerin her bir model için aynı yönde etkiye işaret etmesi söz konusu yorumların yapılmasına imkân veren bir sonuç olmuştur. Ayrıca tüm modeller için hesaplanan McFadden $\mathrm{R}^{2}$ değerleri modellerin açıklama gücünün yüksek olduğunu, Wald testi sonuçları ise her bir model için kullanılan değişkenlerin ilgili model kapsamında bir bütün olarak anlamlı olduğunu göstermektedir. Diğer taraftan uyum iyiliği göstergesi olan LR istatistiğine ait olasılık değerleri de istatistiki olarak anlamlı bulunarak modellerin bütünsel anlamlılığını desteklemiştir. $\mathrm{Bu}$ çerçevede oluşturulan modellerdeki bazı katsayıların düşük olması bağımlı değişkenin nitel olmasından kaynaklanmakla birlikte probit model katsayıları istatistiki olarak anlamlı bulunmuştur. Her bir model için uygulanan LM testi ise Davidson ve MacKinnon (1993) tarafindan önerilen yapay regresyon yöntemi kullanılarak varyans sınaması yapmak amacıyla kullanılmıştır. LM test sonuçları kapsamında herhangi bir varyans problemine rastlanmamış olması modellerin doğru bir şekilde belirlendiğini teyit etmiştir.

Probit model sonuçları değerlendirildiğinde ENF, FAİZ ve LM2 değişkenlerinin finansal kriz olma olasılığı üzerinde pozitif; CA, LDOVIZ, KKO, LKUR, SUE ve LM değişkenlerinin ise negatif yönde etkili olduğu sonucuna ulaşılmıştır. Söz konusu sonuçlara göre, faiz oranlarında yaşanan artışların üretimi azaltması ile enflasyon oranı ve para arzı artışlarının kriz olma olasılığını arttırması teorik beklentilere uygundur. Cari açığın GSYİH içerisindeki payını temsil eden CA değişkeninin negatif katsayıya (Söz konusu değişkenin negatif olması cari açığa, pozitif olması ise cari fazlaya işaret etmektedir.) sahip olması ise dişa bağımlı ekonomiler için büyüme oranını azaltarak kriz yaşanma riskini arttırabilecektir. Ayrıca TCMB döviz varlıklarının azalması merkez bankasının piyasa üzerindeki müdahale gücünü azaltacak ve serbest piyasa ekonomisi şartlarında finansal krizlere zemin hazırlayabilecektir. Bununla birlikte kapasite kullanım oranı ve sanayi üretim endeksinin azalması benzer şekilde üretimde negatif etki yaratarak kriz ortamı için zemin hazırlayan olgulardır. Reel efektif döviz kurunda yaşanan azalmaların kriz olma olasılı̆̆ını arttırması da uluslararası rekabet gücünün azalmasına bağlı olarak gerçekleşebilecektir. Son olarak ithalatta yaşanacak düşüşler ise dış bağımlılık nedeniyle üretimi ve beraberinde büyümeyi olumsuz etkileyerek ekonomiyi kriz ortamına sürükleyebilecektir.

Probit model tahmini değişkenlerin bağımlı değişken üzerindeki etkisinin katsayı yorumunu içermemektedir. $\mathrm{Bu}$ nedenle oluşturulan her bir model kapsamında kullanılan değişken katsayılarını yorumlamak için bağımsız değişkenlerin ortalamaları kullanılarak hesaplanan marjinal etkilerden yararlanılmıştır. İlgili marjinal etki hesaplamaları teorik altyapı kapsamında gerekli formülasyon aşamaları uygulanarak cebirsel olarak hesaplanmıştır. Söz konusu hesaplama ile elde edilen bulgular aşağıdaki tabloda sunulmuştur. 
Tablo 8. Marjinal etki hesaplamaları

\begin{tabular}{|c|c|c|c|c|c|c|c|}
\hline Model & Seri & c & Ort. & pc & $\mathbf{Z}_{\mathbf{i}}$ & $\mathbf{F}\left(\mathbf{Z}_{\mathbf{i}}\right)$ & $\begin{array}{c}\text { Marjinal Etki } \\
\text { Katsayısı }\end{array}$ \\
\hline \multirow{4}{*}{1} & CA & \multirow{4}{*}{$-6,5385$} & $-0,0078$ & $-0,1950$ & \multirow{4}{*}{$-2,6603$} & \multirow{4}{*}{0,0116} & $-0,0023$ \\
\hline & ENF & & $-0,0002$ & 27,6365 & & & 0,3204 \\
\hline & LDOVIZ & & 0,0086 & $-15,6408$ & & & $-0,1813$ \\
\hline & LM2 & & 18,6392 & 0,2155 & & & 0,0025 \\
\hline \multirow{3}{*}{2} & FAIZ & & $-0,1251$ & 0,8176 & \multirow{3}{*}{$-3,9525$} & \multirow{3}{*}{0,0002} & 0,0001 \\
\hline & KKO & 8,2881 & 78,2178 & $-0,1542$ & & & $-0,00002$ \\
\hline & LKUR & & $-0,0007$ & $-23,9153$ & & & $-0,0039$ \\
\hline 3 & SUE & $-3,3667$ & 0,2683 & $-0,0601$ & $-3,5283$ & 0,0008 & $-0,00005$ \\
\hline 4 & LM & $-3,3079$ & 0,0068 & $-3,4318$ & $-3,4788$ & 0,0009 & $-0,0032$ \\
\hline
\end{tabular}

Not: Tabloda yer alan c, ort ve pc parametreleri sırasıyla sabit terim, ortalama ve ilgili değişkenin probit modeline ait katsayısını ifade etmektedir. $\mathrm{Zi}$ ve $\mathrm{f}(\mathrm{Zi})$ ifadeleri ise değişken ortalamaları ve model katsayıları kullanılarak hesaplanan marjinal etki katsayılarının önsel hesaplamalarıdır.

Çalışmada, marjinal etki hesaplaması sonucunda elde edilen bulguların yön bakımından sonuç veren probit model tahminlerinde tespit edilen etki yönü sonuçları ile uyumlu olduğu tespit edilmiştir. Tablo 8'de belirtilen sonuçlara göre, enflasyondaki artışın kriz çıkma olasılığını \%32 oranında artırdığı tespit edilmiştir. Enflasyon oranında yaşanan artışların kriz olasılığını arttırma gücünün yüksek olması bu değişkeninin Türkiye ekonomisi için belirleyici olduğunu göstermektedir. Ayrıca LM2 ve FAİZ değişkenlerinin 1 ay artış göstermesi durumunda kriz olma olasılığı sirasıyla \%0,25 - \%0,0001 oranında artmaktadır. Bulgulara göre, CA değişkeninde gözlenen 1 aylık azalma da kriz olma olasılı̆̆ını \%0,23 arttırmaktadır. Merkez bankasının sahip olduğu döviz rezervlerinde yaşanan artışlar ise bankanın hamle gücünü arttırarak kriz olasılığının azalmasına katkıda bulunabilecektir. Söz konusu katkı oranı \%18,13 olarak tespit edilmiştir. Analiz sonucunda ulaşılan diğer bulgulara göre KKO, LKUR, SUE ve LM değişkenlerinde gözlenen aylık azalışlar kriz olma olasılı̆̆ını üzerinde sırasıyla \%0,002 $\% 0,39$ - \%0,005 - \%0,32 arttırmaktadır.

Çalışmadan elde edilen sonuçlar kapsamında bir değerlendirme yapıldığında Türkiye ekonomisinin analizde kullanılan değişkenlerde yaşanan aylık değişimlerin genel olarak kriz olasılığı üzerindeki etkisinin yön bakımından teorik beklentilerle uygun olduğunu söylemek mümkündür. Bu veriler ışı̆̆ında en etkili değişkenin enflasyon olması Türkiye için şaşırtıcı bir sonuç değildir.

\section{Sonuç ve Öneriler}

Türkiye ekonomisi, özellikle 90'lı yıllardan sonra sık sık karşılaştığı finansal krizler ve literatürde genel kabul görmüş olan öncü kriz göstergelerinde gözlemlenen dalgalanmalar ile birlikte genel olarak oldukça riskli bir ekonomik güzergâhta seyretmektedir. Yaşanan bu süreçte pek çok istikrar programının uygulandığı, para ve maliye politikaları uygulamalarının yanı sıra yapısal değişimlerin öngörüldüğü bilinmektedir. Bu kapsamda pek çok başarılı düzenleme yapıldığını ve ekonominin kırılgan yapısının iyileştirilmeye çalışıldığını söylemek mümkündür. Ancak finansal kriz göstergelerinin ekonomi politikası bağlamında daha hassas bir şekilde ele alınması gerekliliği devam etmektedir.

Bu çalışmada, Türkiye ekonomisinde son 24 yıl içerisinde yaşanan ve bu süreçte gittikçe artan bir öneme sahip olan finansal krizler için literatürde genel kabul görmüş olan kriz 
göstergeleri kullanılarak olasılık etkisi analizi gerçekleştirilmiştir. Bu bağlamda kriz göstergelerinin 1994:01-2018:11 dönemi kapsamında kriz olma olasılığı üzerindeki etki yönü ve derecesi ekonometrik olarak test edilmiştir. Probit model kapsamında elde edilen tahmin sonuçlarının katsayı bağlamında yorumlanamaması nedeniyle marjinal etki hesaplaması kullanılarak katsayı yorumlarına yer verilmiştir. Hesaplanan marjinal etki katsayıları analizde kullanılan bağımsız değişkenlerde gözlenen bir birimlik artış karşısında finansal krizlerin gerçekleşme olasılığında ne kadarlık bir değişim yaşanacağını ifade etmektedir. Bununla birlikte analizdeki her bir model için LM testinden yararlanılarak varyans sınaması gerçekleştirilmiş ve modellerde herhangi bir varyans sorununa rastlanmamıştır.

Probit analizi sonucunda enflasyon oranı, M2 para arzı ve faiz oranında yaşanan artışların kriz olasılığını artırdığı tespit edilmiştir. Buna göre söz konusu değişken değerlerinde yaşanan artışların özellikle büyüme üzerinde yaratacağı azalma etkisi kriz ortamına sebep olabilmektedir. Cari açık endeks/sanayi üretim endeksini kapsayan CA değişkeninin azalması ise dışa bağımlı iç ekonomik yapı gereği büyüme oranını olumsuz etkileyerek kriz olma olasılığını arttırmaktadır. Benzer şekilde TCMB döviz varlıklarının azalması dışa açık ve sermaye hareketliliğinin serbest olduğu piyasa ekonomisi şartlarında finansal krizlerin gerçekleşme olasılığını arttıran bir neden olarak değerlendirilebilir. Ayrıca kapasite kullanım oranı ve sanayi üretim endeksinde gözlemlenen düşüşler üretim üzerinde negatif etki yaratarak kriz yaşanma riskinin artmasına sebep olabilmektedir. Bunun yanı sıra reel efektif döviz kuru ve ithalat azalışları da uluslararası rekabet gücünün düşük, finansal kırılganlık ve üretimde dışa bağımlılık düzeyinin yüksek olması nedeniyle büyümeyi olumsuz etkileyerek kriz ortamına zemin hazırlayabilmektedir. Söz konusu tespitlerin ardından gerçekleştirilen LM testine ait bulgular ile oluşturulan modellerde herhangi bir varyans sorunu olmadığı ortaya konulmuştur. Analizde hesaplanan marjinal etki katsayıları değerlendirildiğinde ise kriz olasıllı̆ı üzerindeki etkisi en fazla olan değişkenin enflasyon oranı olduğu tespit edilmiştir. Bu sonuç 90'lı yıllardan itibaren enflasyon sorunuyla mücadele eden bir ekonomi için şaşırtıcı değildir.

Çalışmadan elde edilen bulgular ışı̆̆ında uzun yıllar boyunca mücadele edilen enflasyon probleminin yanında büyük oranda yapısal eksikliklerden kaynaklandığı düşünülen cari açık sorununun çözümlenmesi ve merkez bankasının sahip olduğu döviz rezervlerini iyileştirici önlemler alınmasının ekonominin öncelikli hedefleri arasında olması gerektiği ifade edilebilir. Ayrıca Türkiye gibi uzun yıllar finansal krizlerle mücadele eden ekonomilerde kriz ortamından kaçınılmak isteniyorsa kriz olasılığını yükselten değişkenlere dair daha hassas politikaların uygulanması önerilebilir.

\section{Kaynakça}

Akçalı, Y. B. (2014). Finansal Krizlerin Öncü Göstergeler Yardımıyla Tahmin Edilmesi ve Türkiye Örneği, İstanbul Üniversitesi Sosyal Bilimler Enstitüsü, Yayınlanmamış Doktora Tezi, İstanbul.

Akın, F. (2002). Ekonometri, Bursa: Beta Basım.

Altıntaş, H. ve Öz, B. (2007). Para Krizlerinin Sinyal Yaklaşımı İle Öngörülebilirliği: Türkiye Uygulamas1, Anadolu Üniversitesi Sosyal Bilimler Dergisi, 7(2): 19-44.

Ascarya, A. (2017). The Real Determinants of Financial Crisis and How to Resolve it in İslamic Economics Perspective, International Journal of Economic Research, 14(3): 501-531.

Avcı, M. A. ve Altay, N. O. (2013). "Finansal Krizlerin Sinyal Yaklaşımı İle Öngörülmesi: Türkiye, Arjantin, Tayland ve İngiltere İçin Bir Analiz", Pamukkale Üniversitesi Sosyal Bilimler Enstitüsü Dergisi, 14: 47-58.

Baltagi, B. H. (1997). Econometrics, New York: Springer. 
Berg, A. ve Catherine, P. (1998). Are Currency Crises Predictable? A Test, IMF Working Paper, No. 154: 1-60.

Calvo, G. A. (1987). Balance of Payments Crises in a Cash-in-Advance Economy, Journal of Money, Credit and Banking, 19(1): 19-32.

Caprio Jr, G., D’Apice, V., Ferri, G., ve Puopolo, G. W. (2014). Macro-Financial Determinants of The Great Financial Crisis: Implications For Financial Regulation, Journal of Banking \& Finance, 44: 114-129.

Cebeci, İ. (2012). Krizleri İncelemede Kullanılan Nitel Tercih Modelleri: Türkiye İçin Bir Probit Model Uygulaması (1988-2009), İstanbul Üniversitesi İktisat Fakültesi Mecmuası, 62(1): 127-146.

Çeşmeci, Ö. ve Önder, A. Özlem (2008). Determinants of Currency Crises in Emerging Markets, Emerging Markets Finance \& Trade, 44(5): 54-67.

Davidson, R. ve MacKinnon, J.G. (1993). Estimation and Inference in Econometrics, New York: Oxford University Press.

Delice, G. (2003). "Finansal Krizler: Teorik ve Tarihsel Bir Perspektif", Erciyes Üniversitesi Iktisadi ve İdari Bilimler Fakültesi Dergisi, 20: 57-81.

Demaris, A. (2004). Regression with Social Data : Modeling Continuous and Limited Response Variables. New Jersey: John Wiley \& Sons, Inc. Hoboken.

Doğan, B. (2009). Türkiye Ekonomisinde Kriz Öncü Göstergeleri ve İkiz Açı, Journal of Azerbaijani Studies, 500-520.

Drazen, A. ve Helpman, E. (1987). Stabilization with Exchange Rate Management, The Quarterly Journal of Economics, 102(4): 835-855.

Eichengreen, B., Rose, A. K. ve Wyplosz, Charles (1995). Exchange Market Mayhem: The Antecedents and Aftermath of Speculative Attacks, Economic Policy, 10(21): 249-312.

Flood, R. P. ve Garber, P. M. (1984). Collapsing Exchange-Rate Regimes: Some Linear Examples, Journal of International Economics, 17(1-2): 1-13.

Frankel, J. A. ve Rose, A. K. (1996). Currency Crashes in Emerging Markets: Empirical Indicators, NBER Working Paper, No:5437: 1-29.

Goldstein, I. ve Razin, A. (2015). Three Branches of Theories of Financial Crises, Foundations and Trends in Finance, 10(2): 113-180.

Gujarat1, D. (1988). Basic Econometrics, McGraw Hill International Edition.

Gujarat1, D. (1995). Basic Econometrics (3. ed.), New York: McGraw-Hill International.

Gujarat1, D. (1999). Temel Ekonometri, (Çev: Ü. Şenesen ve G.G. Şenesen), Birinci Basım, İstanbul: Literatür Yayıncılık.

Imf (1998). Financial Crises:Characteristics and Indicators of Vulnerability, World Economic Outlook, No: 4: 74-97.

Johnston, J. ve Dinardo, J. (1997). Econometric Models, New York: McGraw Hill.

Kaminsky, G. L., Lizondo, S., Reinhart, C. M. (1998). Leading Indicators of Currency Crisis, IMF Staff Papers, 45(1): 1-48.

Kaminsky, G. L. (2003). Varieties of Currency Crisis, NBER Working Paper, No: 10193: 1-29.

Kaminsky, G. L., Lizondo, S. ve Reinhart, C. M. (1998). Leading Indicators of Currency Crises, Policy Research Working Paper, No.1852: 1-42. 
Kaminsky, G. ve C. R. (1996). The Twin Crises: The Causes Of Banking And Balance-OfPayments Problems, Unpublished Manuscript, Federal Reserve Board and International Monetary Fund.

Kaya, V. ve Yılmaz, Ö. (2007). Para Krizleri Öngörüsünde Logit Model ve Sinyal Yaklaşımının Değeri: Türkiye Tecrübesi, Türkiye Ekonomi Kurumu, Tartısma Metni, No. 2007/1: 1-16.

Kayış, A. (2008). SPSS Uygulamalı Çok Değişkenli İstatistik Teknikleri, İçinde: Probit Regresyon Modeli Şeref Kalaycı (Ed.), Ankara: Asil Yayın Dağıtım Ltd. Şti.

Knapp, L. G. ve Seaks, T. G. (1992). An Analysis of the Probability of Default on Federally Guaranteed Student Loans, The Review of Economics and Statistics, 74(3): 404-411.

Korkmaz, Ö. ve Yamak, R. (2015). "Minsky Finansal İstikrarsılılı Hipotezi ve Türkiye Örneği”, Anadolu Üniversitesi Sosyal Bilimler Dergisi, 15(3): 51-70.

Krugman, P. (1979). A Model of Balance-of-Payments Crises, Journal of Money, Credit and Banking, 11(3): 311-325.

Krugman, P. (1998). What Happened to Asia?, http://www.bresserpereira.org.br/Terceiros/Cursos/Krugman-WhatHappenToAsia.pdf (Erişim Tarihi: 02.01.2019).

Lau, L. J. ve Yan, I. K. M. (2002). Predicting Currency Crises with a Nested Logit Model, http://personal.cityu.edu.hk/ efyan/WorkingPapers/ch1nograph_14_102002_per.pdf (Erişim Tarihi: 11.11.2018).

Mariano, R. S., Gultekin, B. N., Ozmucur, S., Shabbir, T., \& Alper, C. E. (2004). Prediction of Currency Crises: Case Of Turkey, Review of Middle East Economics and Finance, 2(2): 87107.

Obstfeld, M. (1986). Rational and Self-Fulfilling Balance-of-Payments Crises, The American Economic Review, 76(1): 72-81.

Obstfeld, M. (1994). The Logic of Currency Crises, Cahiers Economiques et Monetaires, 43: 189-213.

Obstfeld, M. (1996). Models of Currency Crises with Self-Fulfilling Features, European Economic Review, 40: 1037-1047.

Oka, C. (2003). Anticipating Arrears tu the IMF: Early Warning Systems, IMF Working Paper, 03(18): 1-35.

Özer, M. (1999). Finansal Krizler, Piyasa Başarısızlıkları ve Finansal İstikrarı Sağlamaya Yönelik Politikalar, Eskişehir: Anadolu Üniversitesi Yayınları, No:1096.

Sachs, J. (1998). Alternative Approaches to Financial Crises in Emerging Markets, Capital Flows and Financial Crises (Ed.), Miles Kahler, Cornell University Press, Ithaca New York, 243-262.

Sezgin, F. H., ve Özdamar, E. Ö. (2010). Finansal Krizlerin Öngörülmesinde Probit Model Yaklaşımı ve Türkiye Uygulamas1, Uluslararası Finans Sempozyumu-2008, http://bsy.marmara.edu.tr/Konferanslar/2008/27.pdf, (Erişim Tarihi 09.11.2018).

Stanford, J. D. (1998). The Asian Financial Crisis-A Policy Perspective, Economic Analysis and Policy, 28(1): 115-128.

Tosuner, A. (2005). Finansal Krizler ve Kırılganlık: Türkiye İçin Bir Erken Uyarı Sistemi Denemesi, Iktisat İsletme ve Finans, 20(235): 42-61

Train, K. E. (2003). Discrete Choice Methods with Simulation, Cambridge: Cambridge University Press. 
Turan, Z. (2011). "Dünyadaki ve Türkiye'deki Krizlerin Ortaya Çıkış Nedenleri ve Kalkınmaya Etkisi”, Niğde Üniversitesi IİBF Dergisi, 4(1): 56-80.

Uygur, E. (2001). Krizden Krize Türkiye: 2000 Kasım ve 2001 Şubat Krizleri, TEK Tartışma Metni, No. 2001/1, Ankara, 1-40.

Van Wijnbergen, S. (1991). Fiscal Deficits, Exchange Rates Crises and Inflation, Review of Economic Studies, 58(1): 81-92.

Yılmaz, Ö. Kızıltan, A. ve Kaya, V. (2005). "İktisadi Kriz Kuramları, Finansal küreselleşme ve Para Krizleri”, Erciyes Üniversitesi İktisadi ve İdari Bilimler Fakültesi Dergisi, 24: 77-96. 